\title{
Potato Physiological Disorders - Brown Center and Hollow Heart ${ }^{1}$
}

\section{Chad M. Hutchinson ${ }^{2}$}

Brown center and hollow heart are physiological disorders of the potato tuber. Brown center is characterized by a region of cell death in the pith of the tuber which results in brown tissue. Hollow heart is characterized by a star shape hollow in the center of the tuber (Fig. 1). Brown center frequently precedes the development of hollow heart. Neither disorder is initiated by a disease organism.

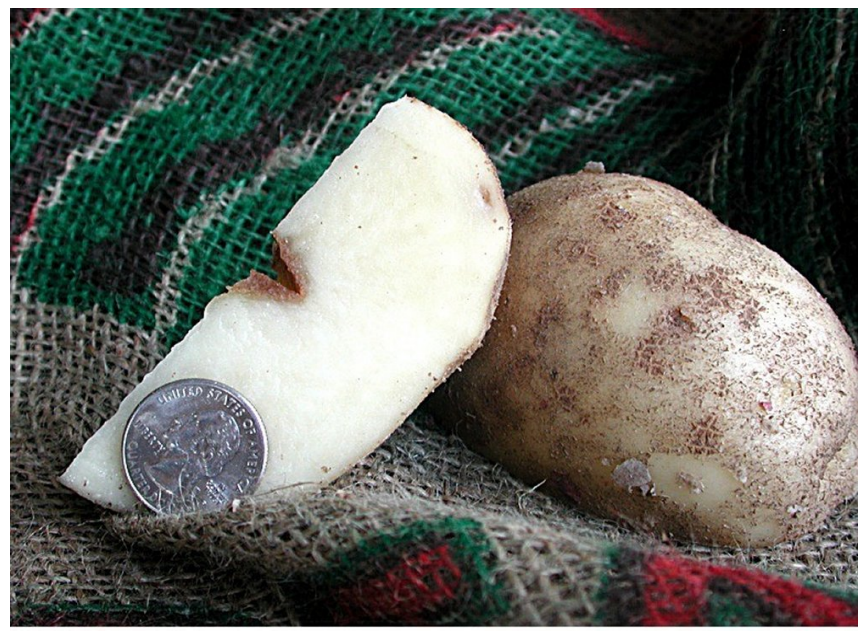

Figure 1. Hollow heart in 'Atlantic'.

Hollow heart and brown center negatively impact tuber quality. The disorders make cut fresh-market tubers unattractive and can reduce repeat sales.
Severe hollow heart negatively impacts the quality of chip processing potatoes and can result in shipments not making grade. However, both disorders are reported as not harmful and do not effect the taste or nutrition of the tuber.

Brown center and hollow heart arise at a higher incidence when growing conditions abruptly change during the season. This can arise when the potato plants recover too quickly after a period of environmental or nutritional stress. When the tubers begin to grow rapidly, the tuber pith can die and/or pull apart leaving a void in the center.

There are differences in the susceptibility of potato varieties to hollow heart and brown center. Atlantic, the most widely grown potato for chip processing in Florida, is relatively susceptible to both disorders. In Atlantic, hollow heart is often seen in conjunction with internal heat necrosis as both disorders are stress related. In Russet Burbank, susceptibility to both brown center and hollow heart is highest soon after tuber initiation when the tubers are small (McCann and Starck, 1989).

To reduce the incidence of brown center and hollow heart, uniform soil moisture should be

1. This document is HS945, one of a series of the Horticultural Sciences Department, Florida Cooperative Extension Service, Institute of Food and Agricultural Sciences, University of Florida. Publication date: August 2003. Please visit the EDIS Web site at http://edis.ifas.ufl.edu.

2. Chad M. Hutchinson, assistant professor, Horticultural Sciences Department, Cooperative Extension Service, Institute of Food and Agricultural Sciences, University of Florida, Gainesville, 32611

The Institute of Food and Agricultural Sciences is an equal opportunity/affirmative action employer authorized to provide research, educational information and other services only to individuals and institutions that function without regard to race, color, sex, age, handicap, or national origin. For information on obtaining other extension publications, contact your county Cooperative Extension Service office. Florida Cooperative Extension Service/Institute of Food and Agricultural Sciences/University of Florida/Christine Taylor Waddill, Dean. 
maintained during the season especially soon after tuber initiation. Nitrogen applications should be split into several applications before row closure to achieve steady plant and tuber growth. Every effort to improve even plant spacing by reducing seed skips at planting should also be made.

Rapid swings in air temperature and rainfall amounts cannot be avoided in Florida production areas. Therefore, it is necessary to properly manage seepage irrigation, nutrient balance, and seed spacing to reduce plant stress and the incidence of brown center and hollow heart.

\section{Further Information}

McCann, I.R. and J.C. Stark. 1989. Irrigation and Nitrogen Management Effects on Potato Brown Center and Hollow Heart. HortScience 24(6):950-952.

Commercial Potato Production in North America. 1993. Potato Association of America Handbook. Revision of American Potato Journal Supplement volume 57 and USDA Handbook 267 by the Extension Section of the Potato Association of America. Edited by; J.B. Sieczka and R.E.

Thornton.

Hochmuth, G.J., C. M. Hutchinson, D. N. Maynard, W. M. Stall, T. A. Kucharek, S. E. Webb, T. G. Taylor, S. A. Smith, and E. H. Simonne. 2001. Potato Production in Florida. In: Vegetable Production Guide for Florida. Edited by; D.N. Maynard and S.M. Olson. Vance Publishing. 